\title{
PENGARUH INVESTASI PMA / PMDN DAN JUMLAH PENDUDUK TERHADAP PRODUK DOMESTIK REGIONAL BRUTO \\ DAN PENDAPATAN ASLI DAERAH KOTA SAMARINDA
}

\author{
DONI JULFIANSYAH \\ Magister Ilmu Ekonomi Fakultas EkonomiUniversitas Mulawarman \\ Jalan Tanah Grogot Gunung Kelua Samarinda Telepon +62541-749067
}

\begin{abstract}
The objective of this study is to investigate and analyze whether or not the influence of foreign investment, domestic investment, and the population of the Gross Regional Domestic Product of Samarinda. In addition, to determine and analyze whether or not the influence of foreign investment, domestic investment, and the population of the city of Samarinda Revenue. Analysis of the data used is multiple linear regression analysis. The results showed that: the first model (1) there is a significant relationship between the variables of foreign investment, domestic investment, and the population of the Gross Regional Domestic Product simultaneously. (2) partially only population that significantly affect the Gross Regional Domestic Product. Whereas the second model results indicate that (1) there is a significant relationship between the variables of foreign investment, domestic investment, and the population of the region income simultaneously. (2) partially no good variable Foreign Investment, Domestic Investment, and the number of people who influence the Revenue.
\end{abstract}

Keywords: Foreign Investment, Domestic Investment, and population

\begin{abstract}
Abstrak
Tujuan diadakannya penelitian ini adalah untuk mengetahui dan menganalisis ada atau tidaknya pengaruh Penanaman Modal Asing, Penanaman Modal Dalam Negeri, dan jumlah penduduk terhadap Produk Domestik Regional Bruto Kota Samarinda. Selain itu, untuk mengetahui dan menganalisis ada atau tidaknya pengaruh Penanaman Modal Asing, Penanaman Modal Dalam Negeri, dan jumlah penduduk terhadap Pendapatan Asli Daerah Kota Samarinda. Analisis data yang digunakan adalah analisis regresi linier berganda. Hasil penelitian menunjukkan bahwa: pada model pertama (1) terdapat hubungan yang signifikan antara variabel Penanaman Modal Asing, Penanaman Modal Dalam Negeri, dan jumlah penduduk terhadap Produk Domestik Regional Bruto secara simultan. (2) secara parsial hanya jumlah penduduk yang berpengaruh secara signifikan terhadap Produk Domestik Regional Bruto. Sedangkan hasil penelitian model kedua menunjukkan bahwa (1) terdapat hubungan yang signifikan antara variabel Penanaman Modal Asing, Penanaman Modal Dalam Negeri, dan jumlah penduduk terhadap Pendapatan Asli Daerah secara simultan. (2) secara parsial tidak ada variabel baik Penanaman Modal Asing, Penanaman Modal Dalam
\end{abstract}


Negeri, dan jumlah penduduk yang berpengaruh terhadap Pendapatan Asli Daerah.

Kata Kunci : Penanaman Modal Asing, Penanaman Modal Dalam Negeri, dan jumlah penduduk

\section{PENDAHULUAN}

Pada saat ini pertumbuhan ekonomi yang tinggi merupakan salah satu indikator untuk menilai keberhasilan pembangunan suatu negara dan menjadi sasaran utama pembangunan bagi banyak negara berkembang. Pelaksanaan pembangunan dimaksudkan untuk mempercepat pencapaian tingkat kesejahteraan hidup yang tinggi bagi penduduknya. Dalam usaha untuk mencapai pertumbuhan ekonomi yang tinggi, pasti ditemukan berbagai hambatan khususnya pada negara yang sedang berkembang. Hambatan yang sering dihadapi oleh negara-negara berkembang adalah dalam hal pendanaan untuk melakukan pembangunan. Hambatan itulah yang juga dialami oleh Indonesia dalam usahanya mencapai pertumbuhan ekonomi yang tinggi.

Indonesia merupakan salah satu dari 3 negara Asia, disamping China dan India yang tetap tumbuh positif saat negara lain terpuruk akibat krisis finansial global. Jumlah penduduk yang tinggi pada ketiga negara tersebut membuat perekonomian tidak terpuruk atas berkurangnya permintaan dari negara lain karena permintaan domestik yang terjaga, yang utamanya didorong oleh konsumsi masyarakat yang tetap tinggi. Di samping itu pemerintah juga memberikan dorongan pada perekonomian melalui peningkatan stimulus dalam mempercepat proses pemulihan perekonomian.

Kesenjangan pembangunan dan pendapatan antar penduduk bukanhanya merupakan masalah pembangunan nasional, tetapi juga oleh Kota Samarinda sebagai bagian integral Negara Kesatuan Republik Indonesia. Sehingga grand strategy Trilogi Pembangunan yang dicanangkan Pemerintah Indonesia juga membawa implikasi kebijakan bagi Kota Samarinda, terlebih kebijakan pembangunan yang 
cenderung sentralistik sebelum era reformasi maka lingkungan strategis kebijakan nasional tersebut sangat berpengaruh terhadap strategi pembangunan di Kota Samarinda.

Salah satu indikator uuntuk mengetahui kondisi ekonomi di suatu wilayah atau kabupaten dalam periode tertentu ditunjukkan oleh data PDRB (Produk Domestik Regional Bruto). PDRB didefinisikan sebagai jumlah nilai tambah yang dihasilkan oleh seluruh unit usaha dalam suatu wilayah, atau merupakan jumlah seluruh nilai barang dan jasa akhir yang dihasilkan oleh seluruh unit ekonomi di suatu wilayah (BPS, 2007 : 2)

\section{Sejak diberlakukannya}

otonomi daerah, masing-masing daerah berbenah diri untuk meningkatkan pendapatannya. Segala potensi yang dimiliki daerah semakin ditingkatkan kemanfaatannya agar dapat mendatangkan pendapatan. Berbagai fasilitas juga dikelola sedemikianrupa sehingga dapat meningkatkan pendapatan dari sektor retribusi. Dari sektor-sektor yang ada tersebut, dengan adanya otonomi daerah semakin memudahkan pemerintah daerah untuk mengelolanya secara maksimal sehingga dapat meningkatkan pendapatan asli daerah yang dapat digunakan untuk melaksanakan pembangunan daerah secara berkesinambungan, terutama di bidang perekonomian agar dapat menunjang pertumbuhan ekonomi secara merata.

Pengembangan sumber daya daerah sebagai upaya meningkatkan penghasilan daerah memerlukan dana sebagai modal atau investasi. Sumber investasi dapat berasal dari masyarakat maupun pemerintah. Sumber investasi masyarakat juga tidak sebatas masyarakat dalam negeri, namun juga masyarakat luar negeri. Sumber investasi dari pemerintah pun juga tidak sebatas pemerintah dalam negeri, namun juga ada investasi yang berasal dari luar negeri. Masing-masing sumber investasi memiliki tujuan dan sasaran sendiri. Baik investasi darimasyarakat atau pemerintah, maupun dari dalam negeri dan luar negeri.

Selain investasi, maka tenaga 
kerja merupakan suatu faktor yang mempengaruhi output suatu daerah. Angkatan kerja yang besar akan terbentuk dari jumlah penduduk yang besar.Kenaikan jumlah penduduk yang cepat, cenderung menurunkantingkat pertumbuhan pendapatan perkapita di sebagian besar negara-negara berkembang, terutama yang kondisi dasarnya masih miskin, tergantung pada sektor pertanian, serta diliputi keterbatasan lahan serta sumber-sumber daya alam (Todaro, 2003:326).

Novita Linda Sitompul pada tahun 2007 telah melakukan penelitian tentang pengaruh investasi terhadap PDRB. Adapun judul penelitian tersebut adalah "Analisis Pengaruh Investasi dan Tenaga Kerja terhadap PDRB Sumatera Utara". Penelitian tersebut didasarkan pada besarnya pengaruh investasi, baik PMDN maupun PMA terhadap PDRB, di mana investasi tersebut juga menyerap sejumlah tenaga kerja sehingga menjadi produktif. Penelitian tersebut bertujuan untuk menganalisis pengaruh investasi, jumlah tenaga kerja, dan kondisi perekonomian Indonesia sebelum dan sesudah krisis ekonomi terhadap PDRB Sumatera Utara. Metode analisis yang digunakan adalah Ordinary Least Square (OLS). Untuk tujuan analisis digunakan data sekunder berupa data time series 1984-2005, yaitu data jumlah tenaga kerja, jumlah investasi PMDN, jumlah investasi PMA di Sumatera Utara dan PDRB Sumatera Utara. Data tersebut diperoleh dari Departemen Tenaga Kerja dan Transmigras, Departemen Perindustrian, BPS, dan sumbersumber lainnya seperti jurnal dan hasil penelitian.

$$
\text { Pada tahun } 2008 \text { Deddy }
$$
Rustiono telah melakukan penelitian tentang pengaruh investasi dan tenaga kerja terhadap pertumbuhan ekonomi. Adapun judul penelitian tersebut adalah "Analisis Pengaruh Investasi, Tenaga Kerja, dan Pengeluaran Pemerintah terhadap Pertumbuhan Ekonomi di Propinsi Jawa Tengah". Penelitian tersebut bertujuan untuk menganalisis pengaruh angkatan kerja, investasi: realisasi PMA, realisasi PMDN, dan belanja pemerintah daerah terhadap PDRB Propinsi Jawa Tengah selama 
kurun waktu 1985-2006. Penelitian yang dilakukan oleh Deddy Rustiono tersebut menggunakan data runtut waktu tahun 1985-2006 dan menggunakan analisis regresi

Ordinary Least Square (OLS) dengan bantuan perangkat lunak SPSS.

Adapun yang menjadi tujuan dari penelitian ini adalah sebagai berikut: 1) Untuk mengetahui dan menganalisis ada atau tidaknya pengaruh antara PMA terhadap PDRB Kota Samarinda; 2) Untuk mengetahui dan menganalisis ada atau tidaknya pengaruh antara PMDN terhadap PDRB Kota Samarinda; 3) Untuk mengetahui dan menganalisis ada atau tidaknya pengaruh antara jumlah penduduk terhadap PDRB Kota Samarinda; 4) Untuk mengetahui dan menganalisis ada atau tidaknya pengaruh PMA terhadap PAD Kota Samarinda; 5) Untuk mengetahui dan menganalisis ada atau tidaknya pengaruh PMDN terhadap PAD Kota Samarinda; 6) Untuk mengetahui dan menganalisis ada atau tidaknya pengaruh jumlah penduduk terhadap PAD Kota Samarinda.

\section{METODE PENELITIAN}

Operasionalisasi variabel diperlukan untuk menentukan jenis, indikator, serta skala dari variabelvariabel yang terkait dalam penelitian sesuai judul penelitian, yakni "Pengaruh Investasi PMA/PMDN dan Jumlah Penduduk terhadap PDRB dan PAD Kota Samarinda". Oleh karena itu variabel-variabel yang terkait dalam penelitian ini adalah sebagai berikut: 1) Variabel $X 1$, Variabel $X 1$ dalam penelitian ini adalah PMA. Variabel PMA dalam penelitian ini diartikan sebagai besarnya penanaman modal oleh sektor swasta asing di Kota Samarinda; 2) Variabel X2, Variabel X2 dalam penelitian ini adalah PMDN. Variabel PMDN dalam penelitian ini diartikan sebagai besarnya penanaman modal oleh sektor swasta dalam negeri di Kota Samarinda; 3) Variabel X3, Variabel X3 dalam penelitian ini adalah jumlah penduduk. Variabel jumlah penduduk dalam penelitian ini diartikan sebagai banyaknya jumlah penduduk di wilayah Kota Samarinda berdasarkan umur dan jenis kelamin pada suatu tertentu; 4) 
Variabel Y1, Variabel Y1 dalam penelitian ini adalah PDRB. Variabel PDRB dalam penelitian ini diartikan sebagai sejumlah nilai tambah yang timbul dari berbagai unit produksi di Kota Samarinda dalam jangka waktu tertentu yang dinyatakan dalam rupiah; 5) Variabel Y2, Variabel Y2 dalam penelitian ini adalah PAD. Variabel PAD dalam penelitian ini diartikan sebagai pendapatan yang diperoleh Kota Samarinda yang dipungut berdasarkan peraturan daerah sesuai dengan peraturan perundang-undangan yaitu pajak daerah, retribusi daerah, hasil pengelolaan kekayaan daerah yang dipisahkan, dan lain-lain PAD yang sah.

\section{PEMBAHASAN}

Pada bab ini akan menelaah kebenaran dari hipotesis penelitian dan akan membahas tentang Pengaruh PMA, PMDN, dan Jumlah Penduduk terhadap PDRB serta Pengaruh PMA, PMDN, dan Jumlah Penduduk terhadap PAD

Dalam model penelitian ini , maka digunakan analisis regresi linear berganda untuk menjawab hipotesis penelitian. Proses analisis dilakukan dengan menggunakan program SPSS. Adapun hasil analisis analisis regresi dapat dijabarkan sebagai berikut: pertama, Model Pertama Regresi Linear Berganda

Hasil penelitian mengguanakan model regresi regresi linear berganda yang diterapkan untuk menguji masing-masing pengaruh variabel independen terhadap variabel dependen. Berdasarkan analisis diperoleh hasil sebagai berikut:

Tabel 1. Coefficients

\begin{tabular}{|c|c|c|c|c|c|c|c|c|}
\hline \multicolumn{9}{|c|}{ Coefficients $^{\mathrm{a}}$} \\
\hline & & \multicolumn{2}{|c|}{ Unstandardized Coefficients } & \multirow{2}{*}{$\begin{array}{c}\begin{array}{c}\text { Standardized } \\
\text { Coefficients }\end{array} \\
\text { Beta }\end{array}$} & \multirow[b]{2}{*}{$t$} & \multirow[b]{2}{*}{ Sig. } & \multicolumn{2}{|c|}{ Collinearity Statistics } \\
\hline \multicolumn{2}{|c|}{ Model } & $\mathrm{B}$ & Std. Error & & & & Tolerance & VIF \\
\hline \multirow[t]{4}{*}{1} & (Constant) & -1174063.1 & 1852071.13 & & -.634 & .561 & & \\
\hline & PMA & .621 & .518 & .175 & 1.198 & .297 & .889 & 1.125 \\
\hline & PMDN & 1.011 & .488 & .327 & 2.073 & .107 & .762 & 1.313 \\
\hline & Jumlah_Penduduk & 15.874 & 3.321 & .751 & 4.780 & .009 & .770 & 1.298 \\
\hline
\end{tabular}

a. Dependent Variable: PDRB

Sumber : Data Diolah 
Berdasarkan tabel di atas maka dapat diambil persamaan regresi sebagai berikut: $\mathrm{Y}=$ $1,174063 \times 10^{6}+0,621 X_{1}+1,1011$ $\mathrm{X}_{2}+15,874 \mathrm{X}_{3} . \quad$ Berdasarkan persamaan tersebut, maka dapat diketahui bahwa: 1) nilai konstanta = $-1,174063 \times 10^{6}$ artinya jika tidak dipengaruhi oleh PMA, PMDN, dan Jumlah Penduduk maka PDRB Kota Samarinda bernilai negatif; 2) Nilai Koefisien PMA (X1) sebesar 0,621 artinya jika PMA bertambah satusatuan, maka akan terjadi peningkatan PDRB Kota Samarinda sebesar Rp 0,621 dengan Asumsi X2 dan X3 Konstan; 3) Nilai Koefisien Tabel 2. Jumlah Penduduk, PMA dan PMDN
PMDN (X2) adalah sebesar 1,011 berarti jika PMDN meningkat satu satuan, maka akan terjadi peningkatan PDRB Kota Samarinda sebesar Rp 1,011 dengan asumsi X1 dan X3 Konstan; 4) Nilai Koefisien Jumlah Penduduk (X3) adalah sebesar 15,874, berarti jika jumlah penduduk meningkat satu saruan, maka akan terjadi peningkatan PDRB Kota Samarinda sebesar Rp 15,874 dengan asumsi X1 dan X2 Konstan.

Adapun berdasarkan model Summary dapat diperoleh hasil analisis sebagai berikut:

Model Summary ${ }^{b}$

\begin{tabular}{|l|l|l|r|r|r|}
\hline Model & R & R Square & $\begin{array}{c}\text { Adjusted R } \\
\text { Square }\end{array}$ & $\begin{array}{c}\text { Std. Error of } \\
\text { the Estimate }\end{array}$ & $\begin{array}{c}\text { Durbin- } \\
\text { Watson }\end{array}$ \\
\hline 1 & $.961^{\mathrm{a}}$ & .924 & .867 & 548317.968 & 1.032 \\
\hline
\end{tabular}

a. Predictors: (Constant), Jumlah_Penduduk, PMA, PMDN

b. Dependent Variable: PDRB

Berdasarkan hasil

perhitungan sebagaimana tersaji pada Tabel 2 di atas, maka koefisien determinasi atau nilai (pada lampiran Regreesion) menunjukkan nilai 0,924 atau $92,4 \%$. Hal tersebut bisa diartikan bahwa 92,4\% nilai PDRB dapat diproksi dengan menggunakan
PMA, PMDN, dan Jumlah Penduduk, sedangkan sisanya sebesar 7,6\% dijelaskan oleh variabel-variabel lain diluar variabel PMA, PMDN, dan Jumlah Penduduk. Nilai $\mathrm{R}^{2}$ dalam penelitian ini relatif tinggi, sehingga bisa dikatakan bahwa variabel PMA, 
PMDN, dan Jumlah Penduduk berpotensi memberikan berpengaruh yang besar terhadap nilai PDRB Kota Samarinda.

Untuk menguji hipotesis pertama yaitu apakah variabel bebas (independent) secara bersama-sama memberikan pengaruh atau tidak terhadap variabel tidak bebas (dependent) dapat dilihat dari hasil uji F, sedangkan untuk menguji hipotesis kedua yaitu apakah secara farsial variabel bebas berpengaruh nyata terhadap variabel tidak bebas maka digunakan uji t.
Uji $\mathrm{t}$ dilakukan untuk mengetahui apakah ada pengaruh secara parsial variabel bebas terhadap variabel terikat. Adapun kriteria yang digunakan untuk melihat pengaruh secara parsial dari variabel terikat dengan variabel terikat dengan cara melihat nilai $\mathrm{p}$ value (probabilitas) pada Tabel Cofficients.

Dari hasil perhitungan dengan SPSS versi 20 terlihat bahwa nilai $\mathrm{t}$ adalah sebagai berikut:

Tabel 3. Hasil Perhitungan thitung untuk Pengaruh PMA terhadap PDRB Kota Samarinda

\begin{tabular}{cccc}
\hline Variabel & t hitung & $\mathrm{p}$ value & Keterangan \\
\hline PMA & 1,198 & 0,297 & $\begin{array}{c}\text { Tidak } \\
\text { Signifikan }\end{array}$ \\
\hline
\end{tabular}

Berdasarkan Tabel 3 dapat alpha 5\%. Sehingga hasil diartikan bahwa tidak terdapat perhitungan menunjukkan bahwa pengaruh signifikansi variabel PMA PMA tidak berpengaruh secara terhadap PDRB. Hal tersebut terlihat positif dan signifikan terhadap nilai dari nilai probabilitas $(0,297)$ PDRB Kota Samarinda.

memiliki nilai lebih besar dari nilai

Tabel 4. Hasil Perhitungan t hitung untuk Pengaruh PMDN terhadap PDRB Kota Samarinda

\begin{tabular}{cccc}
\hline Variabel & t hitung & $\mathrm{p}$ value & Keterangan \\
\hline PMDN & 2,073 & 0,107 & $\begin{array}{c}\text { Tidak } \\
\text { Signifikan }\end{array}$ \\
\hline
\end{tabular}


Berdasarkan Tabel 4 dapat alpha 5\%. Sehingga hasil diartikan bahwa tidak terdapat perhitungan menunjukkan bahwa pengaruh signifikansi variabel PMDN tidak berpengaruh secara PMDN terhadap PDRB. Hal tersebut positif dan signifikan terhadap nilai terlihat dari nilai probabilitas $(0,107)$ PDRB Kota Samarinda. memiliki nilai lebih besar dari nilai

Tabel 5. Hasil Perhitungan t hitung untuk Pengaruh Jumlah Penduduk terhadap PDRB Kota Samarinda

\begin{tabular}{cccc}
\hline Variabel & t hitung & $\mathrm{p}$ value & Keterangan \\
\hline Jumlah Penduduk & 4,780 & 0,009 & Signifikan \\
\hline
\end{tabular}

Berdasarkan Tabel 5. dapat diartikan bahwa tidak terdapat pengaruh signifikansi variabel jumlah penduduk terhadap PDRB. Hal tersebut terlihat dari nilai probabilitas $(0,009)$ memiliki nilai Tabel 6. Hasil Perhitungan ANOVA lebih kecil dari nilai alpha $5 \%$. Sehingga hasil perhitungan menunjukkan bahwa jumlah penduduk berpengaruh secara positif dan signifikan terhadap nilai PDRB Kota

Samarinda.

ANOVA $^{\mathrm{a}}$

\begin{tabular}{|c|c|c|c|c|c|c|}
\hline & & $\begin{array}{l}\text { Sum of } \\
\text { Squares }\end{array}$ & df & Mean Square & $\mathrm{F}$ & Sig. \\
\hline \multirow[t]{3}{*}{1} & Regression & $1.462 \mathrm{E}+13$ & 3 & $4.872 \mathrm{E}+12$ & 16.205 & $.011^{\mathrm{b}}$ \\
\hline & Residual & $1.203 E+12$ & 4 & $3.007 E+11$ & & \\
\hline & Total & $1.582 \mathrm{E}+13$ & 7 & & & \\
\hline
\end{tabular}

a. Dependent Variable: PDRB

b. Predictors: (Constant), Jumlah_Penduduk, PMA, PMDN

Berdasarkan Tabel 6, terlihat bahwa hasil uji $\mathrm{F}$ pada perhitungan data penelitian menggunakan program SPSS versi 20.0. Nilai F hitung pada hasil perhitungan adalah sebesar 16,205 dengan nilai probabilitas (p-value) sebesar 0,011. Nilai $\mathrm{p}$ value selanjutnya dikonsultasikan dengan nilai alpha.
Berdasarkan perhitungan langkah di atas, menunjukkan bahwa model penelitian yang digunakan sudah tepat. Dengan kata lain, terdapat pengaruh yang simultan dari variabel PMA, PMDN, dan Jumlah Penduduk terhadap nilai PDRB Kota Samarinda. 
Suatu model yang baik harus memenuhi kriteria BLUE (Best Linear Suatu model yang baik harus memenuhi kriteria BLUE (Best Linear Unbiased Estimator) yaitu memenuhi asumsi klasik (Gujarati, 1995). Dalam regresi terdapat beberapa asumsi dasar yang menghasilkan estimator linier tidak bias. Dengan memenuhi beberapa asumsi tersebut, maka hasil yang diperoleh dapat lebih akurat dan mendekati kenyataan. Asumsiasumsi dasar tersebut dikenal dengan asumsi klasik. Penyimpangan asumsi klasik akan sangat berpengaruh terhadap pola perubahan variabel dependen.

Uji multikolonieritas bertujuan untuk menguji apakah model regresi ditemukan adanya korelasi antar variabel independen. Model regresi yang baik seharusnya tidak terjadi korelasi di antara variabel independen. Uji multikolonieritas dilakukan dengan menghitung nilai variance inflation factor (VIF). Berdasarkan hasil perhitungan dengan menggunakan SPSS versi 20, diperoleh hasil sebagai

berikut:

Tabel 7. Perhitungan Nilai Variance Inflation Factor (VIF)

\begin{tabular}{lcc}
\hline Variabel & Nilai VIF & Keterangan \\
\hline PMA & 1,125 & $\begin{array}{c}\text { tidak terjadi } \\
\text { multikolinearitas }\end{array}$ \\
\hline PMDN & 1,313 & $\begin{array}{c}\text { tidak terjadi } \\
\text { multikolinearitas }\end{array}$ \\
\hline Jumlah Penduduk & 1,298 & $\begin{array}{c}\text { tidak terjadi } \\
\text { multikolinearitas }\end{array}$ \\
\hline
\end{tabular}

Berdasarkan Tabel 7, dapat diperoleh hasil bahwa variabel PMA memiliki nilai VIF sebesar 1,125 , variabel PMDN memiliki nilai VIF sebesar 1,313, variabel Jumlah Penduduk memiliki nilai VIF sebesar 1,298. Angka VIF tersebut lebih kecil dari 10, sehingga dapat diartikan bahwa tidak ditemukan adanya korelasi antar variabel independen.

Heteroskedastisitas artinya varians variabel dalam model tidak sama (konstan). Konsekuensinya adalah penaksir yang diperoleh tidak efisien, baik dalam sampel kecil 
maupun besar. Untuk menguji hasil estimasi suatu model regresi terdapat heteroskedastisitas atau tidak dalam penelitian ini digunakan Grafik Plot antara prediksi variabel terikat dengan residualnya.
Berdasarkan

hasil perhitungan dengan menggunakan SPSS diperoleh grafik sebagai berikut:

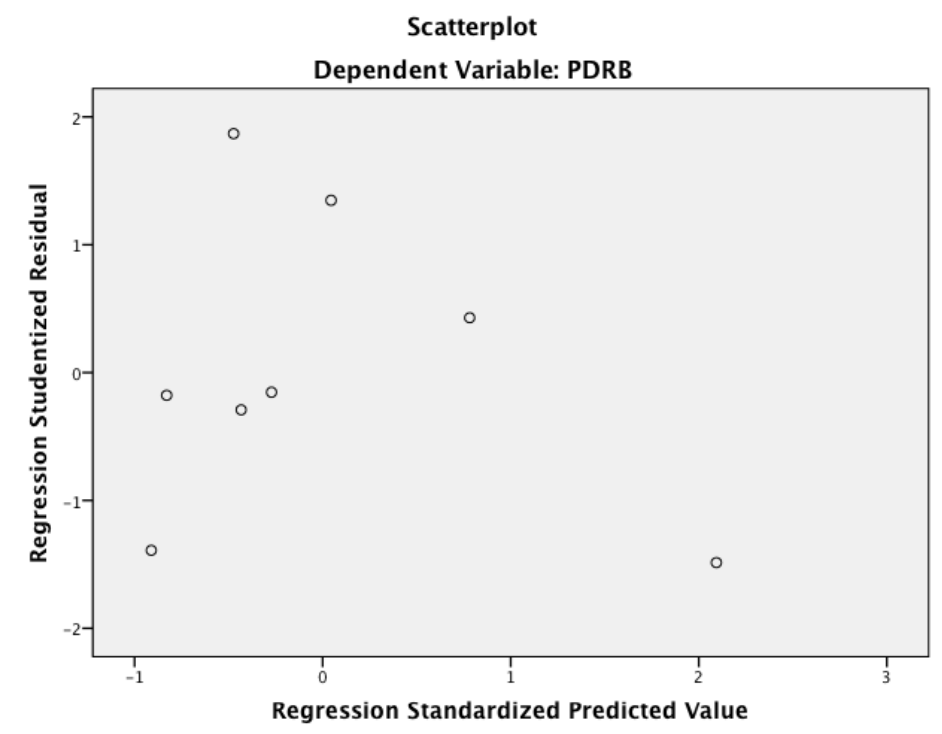

Gambar. 1. Scatterplots

Dari grafik scatterplots dilihat bahwa titik-titik menyebar secara acak baik di atas maupun di bawah angka 0 pada sumbu Y. Hal ini dapat disimpulkan bahwa tidak terjadi heteroskedastisitas pada model regresi, sehingga model regresi layak untuk digunakan.

Uji autokorelasi bertujuan untuk menguji apakah dalam suatu model regresi linier ada korelasi $\mathrm{f}(\mathrm{d})$ antara residual (kesalahan pengganggu) pada periode $t$ dengan residual pada periode $\mathrm{t}-1$ (sebelumnya). Untuk mendeteksi ada tidaknya autokorelasi bisa dilihat menggunakan cara statistik dari besaran Durbin-Watson. Adapun kaidah keputusan dari uji DW adalah sebagai berikut: 


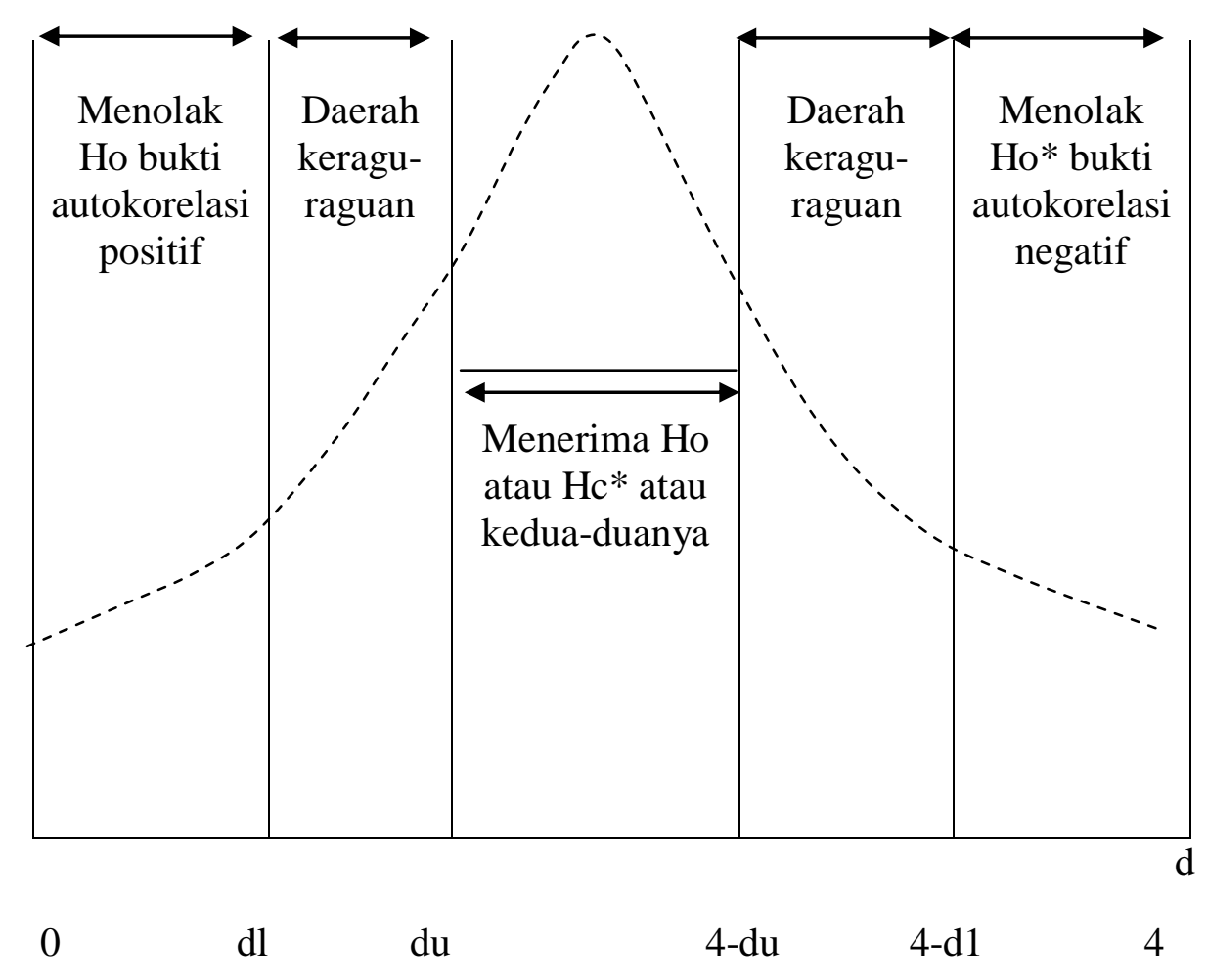

Sumber : data diolah

Gambar 2. Uji Durbin-Watson Test (D-W Test)

Pada k (banyaknya variabel independent) $=3$ dan $\mathrm{n}=8$ serta $\square \square=0,05$ diperoleh nilai kritis dari persamaan model:

Nilai dl $=0,368$ dan $4-\mathrm{dl}=3,632$

Nilai $d u=2,287$ dan 4-du $=2,713$

Hasil perhitungan dengan SPSS 20 diperoleh nilai statistik Durbin-Watson sebesar 1,032. Ini berarti bahwa berlaku

dl $<$ d DW $<\mathrm{du}$

$\mathrm{dl}=0,368<\mathrm{d} \mathrm{DW}=1,032<4-$ $\mathrm{du}=2,287$.

Ini berarti bahwa tidak terjadi autokorelasi positif pada model, jadi tidak ada hubungan antara residual (kesalahan pengganggu) pada periode $\mathrm{t}$ dengan residual pada periode $\mathrm{t}-1$ pada persamaan 1 .

Berdasarkan hasil penjabaran di atas, terlihat bahwa tidak terjadi pelanggaran asumsi klasik, baik pada uji multikolinearitas, uji heteroskedastisitas, dan uji autokorelasi. Dengan demikian, model regresi linear berganda dapat digunakan untuk mengetahui pengaruh PMA, PMDN, dan Jumlah Penduduk terhadap nilai PDRB Kota Samarinda. 
Model kedua berikutnya diperoleh hasil sebagai berikut:

Tabel 8. Coefficients

Coefficients $^{\mathrm{a}}$

\begin{tabular}{|c|c|c|c|c|c|c|c|c|}
\hline \multirow[b]{2}{*}{ Model } & & \multicolumn{2}{|c|}{ Unstandardized Coefficients } & \multirow{2}{*}{$\begin{array}{c}\begin{array}{c}\text { Standardized } \\
\text { Coefficients }\end{array} \\
\text { Beta }\end{array}$} & \multirow[b]{2}{*}{$\mathrm{t}$} & \multirow[b]{2}{*}{ Sig. } & \multicolumn{2}{|c|}{ Collinearity Statistics } \\
\hline & & B & Std. Error & & & & Tolerance & VIF \\
\hline & (Constant) & $-1.042 E+11$ & $5.922 \mathrm{E}+10$ & & -1.760 & .153 & & \\
\hline & PMA & 6418.092 & 16572.557 & .095 & .387 & .718 & .889 & 1.125 \\
\hline & PMDN & 20184.187 & 15593.315 & .344 & 1.294 & .265 & .762 & 1.313 \\
\hline & Jumlah_Penduduk & 272224.875 & 106185.371 & .677 & 2.564 & .062 & .770 & 1.298 \\
\hline
\end{tabular}

a. Dependent Variable: PAD

Sumber : Data Diolah

Berdasarkan tabel 8 maka

dapat diambil persamaan regresi sebagai berikut: $\mathrm{Y}=-1,042 \times 10^{11}+$ $6418,092 \mathrm{X}_{1}+20184,187 \mathrm{X}_{2}+$ 272224,875 $\mathrm{X}_{3}$. Dimana, $\mathrm{Y}=\mathrm{PAD}$; $\mathrm{X}_{1}=$ PMA $; \mathrm{X}_{2}=\mathrm{PMDN} ; \mathrm{X}_{3}=$ Jumlah Penduduk

Berdasarkan persamaan di atas, maka dapat diketahui bahwa: pertama, Nilai Konstanta $=-1,042 \mathrm{x}$ $10^{11}$ artinya jika tidak dipengaruhi oleh PMA, PMDN, dan Jumlah Penduduk, maka PAD Kota Samarinda bernilai negatif. Kedua, Nilai Koefisien PMA (X1) sebesar 6418,092 artinya jika PMA bertambah satu-satuan, maka akan terjadi peningkatan PAD Kota Samarinda sebesar Rp 6418,092 dengan Asumsi X2 dan X3 Konstan. Ketiga, Nilai Koefisien PMDN (X2) adalah sebesar 20184,187 berarti jika PMDN meningkat satu satuan, maka akan terjadi peningkatan PAD Kota Samarinda sebesar Rp 20184,187 dengan asumsi X1 dan X3 Konstan. Keempat, Nilai Koefisien Jumlah Penduduk (X3) adalah sebesar 272224,875, berarti jika jumlah penduduk meningkat satu satuan, maka akan terjadi peningkatan PAD Kota Samarinda sebesar Rp 272224,875 dengan asumsi X1 dan X2 Konstan.

Berdasarkan hasil perhitungan sebagaimana tersaji pada Tabel 9, maka koefisien determinasi atau nilai (pada lampiran Regreesion) menunjukkan nilai 0,785 atau $78,5 \%$. Hal tersebut bisa diartikan bahwa 78,5\% nilai PAD dapat diproksi dengan menggunakan PMA, PMDN, dan Jumlah Penduduk, sedangkan sisanya sebesar 21,5\% dijelaskan oleh variabel-variabel lain diluar variabel 
PMA, PMDN, dan Jumlah

PMDN, dan Jumlah Penduduk

Penduduk. Nilai $\mathrm{R}^{2}$ dalam penelitian berpotensi memberikan berpengaruh ini relatif tinggi, sehingga bisa yang besar terhadap nilai PAD Kota dikatakan bahwa variabel PMA, Samarinda.

Tabel 9. Hasil Perhitungan Model Summary

Model Summary ${ }^{\text {b }}$

\begin{tabular}{|l|l|r|r|r|r|}
\hline Model & $R$ & R Square & $\begin{array}{c}\text { Adjusted R } \\
\text { Square }\end{array}$ & $\begin{array}{c}\text { Std. Error of } \\
\text { the Estimate }\end{array}$ & $\begin{array}{c}\text { Durbin- } \\
\text { Watson }\end{array}$ \\
\hline 1 & $.886^{\mathrm{a}}$ & .785 & .624 & $1.7532 \mathrm{E}+10$ & .839 \\
\hline
\end{tabular}

a. Predictors: (Constant), Jumlah_Penduduk, PMA, PMDN

b. Dependent Variable: PAD

Untuk menguji hipotesis pertama yaitu apakah variabel bebas (independent) secara bersama-sama memberikan pengaruh atau tidak terhadap variabel tidak bebas (dependent) dapat dilihat dari hasil uji F, sedangkan untuk menguji hipotesis kedua yaitu apakah secara farsial variabel bebas berpengaruh nyata terhadap variabel tidak bebas maka digunakan uji t.

Uji $t$ dilakukan untuk mengetahui apakah ada pengaruh secara parsial variabel bebas terhadap variabel terikat. Adapun kriteria yang digunakan untuk melihat pengaruh secara parsial dari variabel terikat dengan variabel terikat dengan cara melihat nilai $\mathrm{p}$ value (probabilitas) pada Tabel Cofficients.

Dari hasil perhitungan dengan SPSS versi 20 terlihat bahwa nilai t disajikan dalam tabel 10 .

Berdasarkan Tabel 10 dapat diartikan bahwa tidak terdapat pengaruh signifikansi variabel PMA terhadap PDRB. Hal tersebut terlihat dari nilai probabilitas $(0,718)$ memiliki nilai lebih besar dari nilai alpha 5\%. Sehingga hasil perhitungan menunjukkan bahwa PMA tidak berpengaruh secara positif dan signifikan terhadap nilai PDRB Kota Samarinda.

Tabel 10. Hasil Perhitungan thitung Pengaruh PMA terhadap PAD Kota Samarinda

\begin{tabular}{cccc}
\hline Variabel & t hitung & $\mathrm{p}$ value & Keterangan \\
\hline PMA & 0,387 & 0,718 & $\begin{array}{c}\text { Tidak } \\
\text { Signifikan }\end{array}$ \\
\hline
\end{tabular}


Tabel 11. Hasil Perhitungan thitung Pengaruh PMDN terhadap PAD Kota Samarinda

\begin{tabular}{cccc}
\hline Variabel & t hitung & $\mathrm{p}$ value & Keterangan \\
\hline PMDN & 1,294 & 0,265 & $\begin{array}{c}\text { Tidak } \\
\text { Signifikan }\end{array}$ \\
\hline
\end{tabular}

Berdasarkan Tabel 11 dapat alpha 5\%. Sehingga hasil diartikan bahwa tidak terdapat perhitungan menunjukkan bahwa pengaruh signifikansi variabel PMDN tidak berpengaruh secara PMDN terhadap PAD. Hal tersebut positif dan signifikan terhadap nilai terlihat dari nilai probabilitas $(0,265) \quad$ PAD Kota Samarinda. memiliki nilai lebih besar dari nilai

Tabel 12. Hasil Perhitungan t hitung Pengaruh Jumlah Penduduk terhadap PAD Kota Samarinda

\begin{tabular}{|c|c|c|c|}
\hline Variabel & t hitung & $\mathrm{p}$ value & Keterangan \\
\hline Jumlah Penduduk & 2,564 & 0,062 & Signifikan \\
\hline
\end{tabular}

Berdasarkan Tabel 12 dapat diartikan bahwa tidak terdapat pengaruh signifikansi variabel jumlah penduduk terhadap PAD. Hal tersebut terlihat dari nilai probabilitas $(0,062)$ memiliki nilai Tabel 13. Hasil Perhitungan ANOVA lebih kecil dari nilai alpha 5\%. Sehingga hasil perhitungan menunjukkan bahwa jumlah penduduk tidak berpengaruh secara positif dan signifikan terhadap nilai PDA Kota Samarinda.

ANOVA $^{\mathrm{a}}$

\begin{tabular}{|c|c|c|c|c|c|c|}
\hline & & $\begin{array}{l}\text { Sum of } \\
\text { Squares }\end{array}$ & df & Mean Square & $\mathrm{F}$ & Sig. \\
\hline \multirow[t]{3}{*}{1} & Regression & $4.489 \mathrm{E}+21$ & 3 & $1.496 \mathrm{E}+21$ & \multirow[t]{3}{*}{4.868} & \multirow[t]{3}{*}{$.080^{\mathrm{b}}$} \\
\hline & Residual & $1.229 \mathrm{E}+21$ & 4 & $3.074 E+20$ & & \\
\hline & Total & $5.718 \mathrm{E}+21$ & 7 & & & \\
\hline
\end{tabular}

a. Dependent Variable: PAD

b. Predictors: (Constant), Jumlah_Penduduk, PMA, PMDN

Berdasarkan Tabel 13, 20.0. Nilai $F$ hitung pada hasil terlihat bahwa hasil uji $\mathrm{F}$ pada perhitungan adalah sebesar 4,868 perhitungan data penelitian dengan nilai probabilitas ( $\mathrm{p}$-value) menggunakan program SPSS versi sebesar 0,080. Nilai $\mathrm{p}$ value 
selanjutnya dikonsultasikan dengan nilai alpha. Berdasarkan perhitungan langkah di atas, menunjukkan bahwa model penelitian yang digunakan tidak tepat. Dengan kata lain, tidak terdapat pengaruh yang simultan dari variabel PMA, PMDN, dan Jumlah Penduduk terhadap nilai PAD Kota Samarinda.

Suatu model yang baik harus memenuhi kriteria BLUE (Best Linear Suatu model yang baik harus memenuhi kriteria BLUE (Best Linear Unbiased Estimator) yaitu memenuhi asumsi klasik (Gujarati, 1995). Dalam regresi terdapat beberapa asumsi dasar yang menghasilkan estimator linier tidak bias. Dengan memenuhi beberapa asumsi tersebut, maka hasil yang diperoleh dapat lebih akurat dan mendekati kenyataan. Asumsiasumsi dasar tersebut dikenal dengan asumsi klasik. Penyimpangan asumsi klasik akan sangat berpengaruh terhadap pola perubahan variabel dependen.

Uji multikolonieritas bertujuan untuk menguji apakah model regresi ditemukan adanya korelasi antar variabel independen. Model regresi yang baik seharusnya tidak terjadi korelasi di antara variabel independen. $\mathrm{Uji}$ multikolonieritas dilakukan dengan menghitung nilai variance inflation factor (VIF). Berdasarkan hasil perhitungan dengan menggunakan SPSS versi 20, diperoleh hasil sebagai berikut:

Tabel 14. Perhitungan Nilai Variance Inflation Factor (VIF)

\begin{tabular}{lcc}
\hline \multicolumn{1}{c}{ Variabel } & Nilai VIF & Keterangan \\
\hline PMA & 1,125 & $\begin{array}{c}\text { tidak terjadi } \\
\text { multikolinearitas }\end{array}$ \\
\hline PMDN & 1,313 & $\begin{array}{c}\text { tidak terjadi } \\
\text { multikolinearitas }\end{array}$ \\
\hline Jumlah Penduduk & 1,298 & $\begin{array}{c}\text { tidak terjadi } \\
\text { multikolinearitas }\end{array}$ \\
\hline
\end{tabular}

Berdasarkan Tabel di atas, dapat diperoleh hasil bahwa variabel PMA memiliki nilai VIF sebesar 1,125 , variabel PMDN memiliki nilai VIF sebesar 1,313, variabel Jumlah
Penduduk memiliki nilai VIF sebesar 1,298. Angka VIF tersebut lebih kecil dari 10, sehingga dapat diartikan bahwa tidak ditemukan 
adanya korelasi antar variabel independen.

Heteroskedastisitas artinya varians variabel dalam model tidak sama (konstan). Konsekuensinya adalah penaksir yang diperoleh tidak efisien, baik dalam sampel kecil maupun besar. Untuk menguji hasil heteroskedastisitas atau tidak dalam penelitian ini digunakan Grafik Plot antara prediksi variabel terikat dengan residualnya.

Berdasarkan hasil perhitungan dengan menggunakan SPSS diperoleh grafik sebagai berikut:

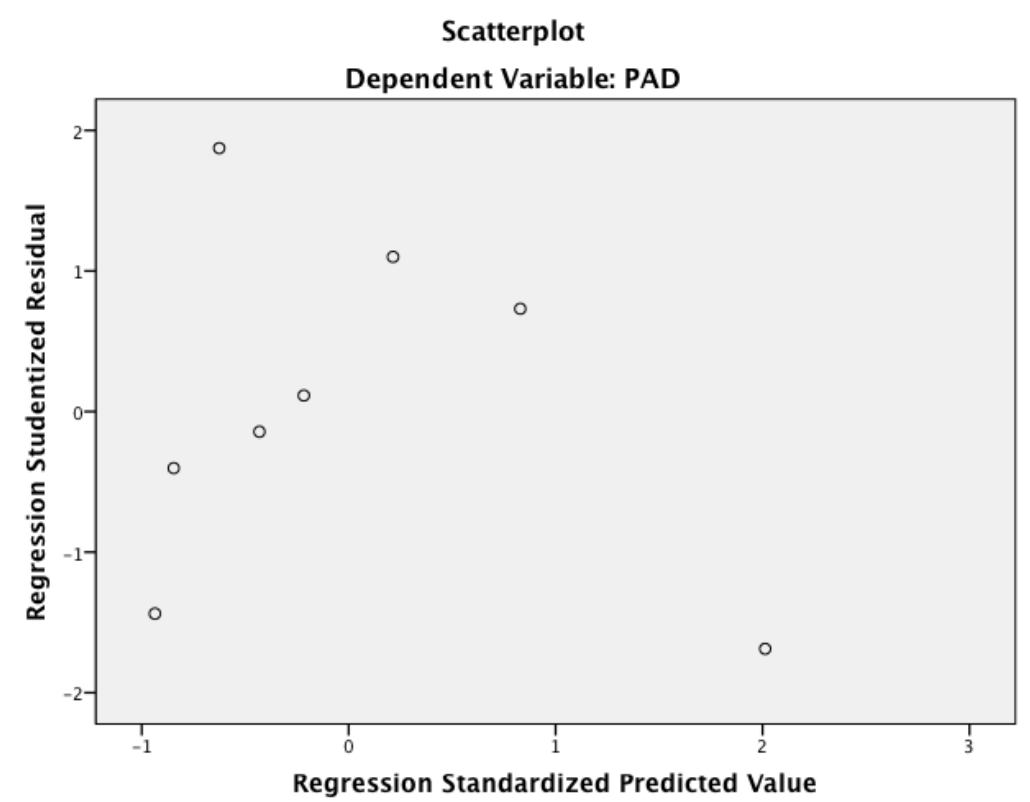

Gambar 3. Scatterplots

Dari grafik scatterplots dilihat

bahwa titik-titik menyebar secara acak baik di atas maupun di bawah angka 0 pada sumbu Y. Hal ini dapat disimpulkan bahwa tidak terjadi heteroskedastisitas pada model regresi, sehingga model regresi layak untuk digunakan.
Uji autokorelasi bertujuan untuk menguji apakah dalam suatu model regresi linier ada korelasi antara residual (kesalahan pengganggu) pada periode $t$ dengan residual pada periode $\mathrm{t}-1$ (sebelumnya). Untuk mendeteksi ada tidaknya autokorelasi bisa dilihat menggunakan cara statistik dari 
besaran Durbin-Watson. Adapun sebagai berikut: kaidah keputusan dari uji DW adalah

$\mathrm{f}(\mathrm{d})$

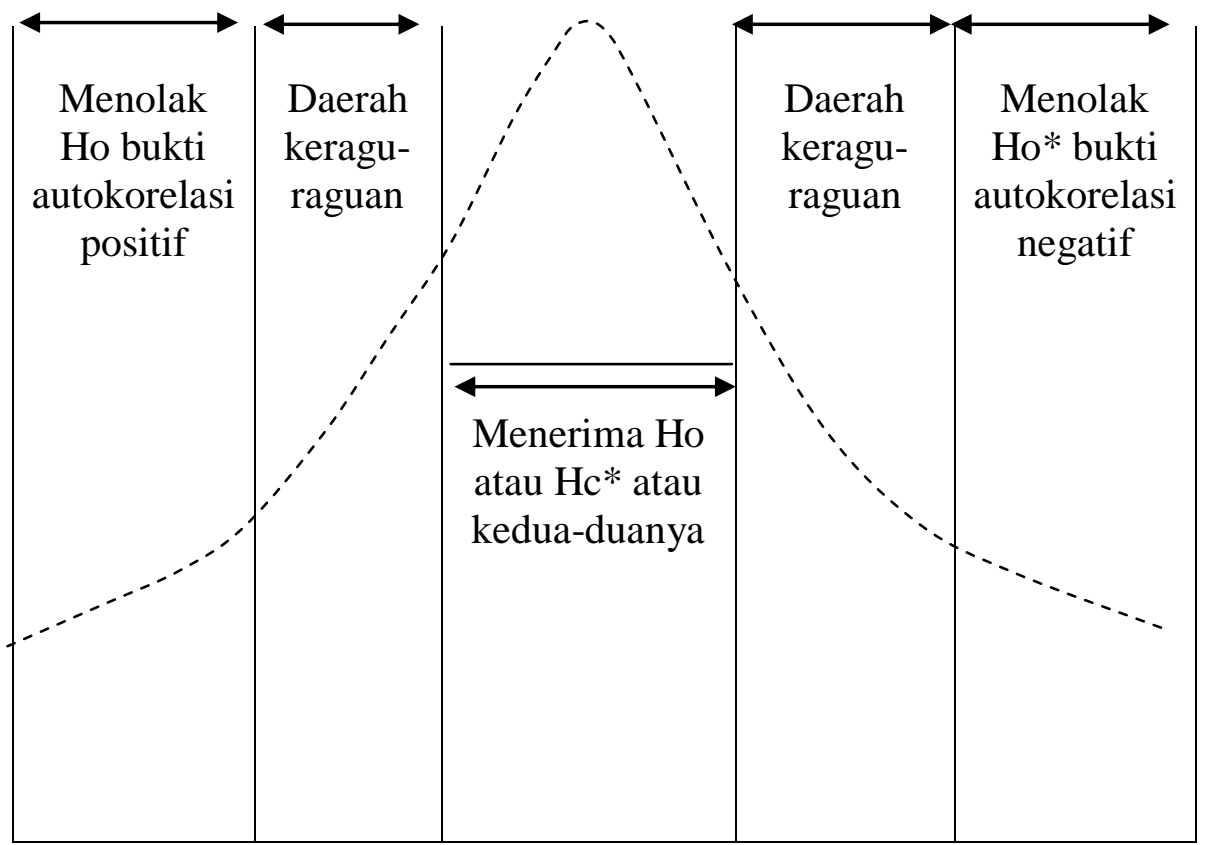

$\begin{array}{llllll}0 & \mathrm{dl} & \mathrm{du} & 4-\mathrm{du} & 4-\mathrm{d} 1 & 4\end{array}$

Sumber : data diolah

Gambar 4. Uji Durbin-Watson Test (D-W Test)

Pada k (banyaknya variabel

independent) $=3$ dan $\mathrm{n}=8$ serta

$\square \square=0,05$ diperoleh nilai kritis dari persamaan model:

Nilai $\mathrm{dl}=0,368$ dan $4-\mathrm{dl}=3,632$

Nilai du $=2,287$ dan 4-du $=2,713$

Hasil perhitungan dengan SPSS 20 diperoleh nilai statistik

Durbin-Watson sebesar 0,839. Ini berarti bahwa berlaku

dl $<$ d DW $<\mathrm{du}$ $\mathrm{dl}=0,368<\mathrm{d} \mathrm{DW}=0,839<4-$ $\mathrm{du}=2,287$.

Ini berarti bahwa tidak terjadi autokorelasi positif pada model, jadi tidak ada hubungan antara residual (kesalahan pengganggu) pada periode $\mathrm{t}$ dengan residual pada periode $\mathrm{t}-1$ pada persamaan 1 .

Berdasarkan hasil penjabaran gambar 4, terlihat bahwa tidak terjadi pelanggaran asumsi klasik, baik pada uji multikolinearitas, uji 
heteroskedastisitas, dan uji sandang fasilitas pendidikan, autokorelasi. Dengan demikian, kesehatan dan penyediaan model regresi linear berganda dapat kesempatan kerja bagi masyarakat digunakan untuk mengetahui pengaruh PMA, PMDN, dan Jumlah Penduduk terhadap nilai PDRB Kota Samarinda.

Berdasarkan hasil perhitungan analisis yang telah diuraikan, terlihat bahwa hanya model pertama yang layak dilanjutkan, sedangkan model kedua tidak bias digunakan. Adapun hasil pengujian hipotesis berdasarkan analisis regresi linear berganda, terihat bahwa hanya Hipotesis Kedua yang terbukti, yaitu terdapat pengaruh yang signifikan antara Jumlah Penduduk dengan PDRB kota Samarinda.

Adanya jumlah penduduk dan angkatan kerja yang cukup besar di satu pihak menggambarkan potensi yang dikerahkan untuk usaha produktif yaitu yang dapat menghasilkan barang dan jasa untuk memenuhi kebutuhan sehari- hari. Disisi lain, hal tersebut memberikan gambaran betapa besarnya tantangan yang dihadapi terutama dalam hal penyediaan bahan makanan, papan, tersebut. Keadaan ini menunjukan adanya permasalahan dalam ketanaga kerjaan dan masalah ini tidak berdiri sendiri akan tetapi akan mempunyai kaitan yang lebih komplek karena terkait pada sektor yang lain. Sebaliknya kelangkaan tenaga kerja di Kota Samarinda dapat akan berdampak pada pengalokasian tenaga kerja. Akibat selanjutnya adalah akan terjadi ketimpangan dan penurunan kondisi perekonomian.

Hal ini membuktikan bawah perubahan kuantitas tenaga kerja akan berpengaruh pada tingkat produksi karena tenaga kerja merupakan salah satu komponen dari faktor produksi. Bila kuantitas tenaga kerja meningkat, maka hasil produksi (PDB) akan meningkat pula.

\section{KESIMPULAN}

Berdasarkan analisis data dan pembahasan yang telah disajikan pada bab terdahulu, maka dapat ditarik kesimpulan dalam penelitian ini adalah tingkat korelasi variabel PMA, PMDN, dan Jumlah Penduduk 
tersebut menunjukkan adanya hubungan yang signifikan secara simultan (keseluruhan) sebesar 96,1\%. Kemudian koefisien determinasi sebesar $92,4 \%$ yang menunjukkan bahwa variabelvariabel independen (PMA, PMDN, Jumlah Penduduk) yang digunakan dapat menjelaskan model sebesar 92,4\% terhadap PDRB sedangkan sisanya sebesar $7,6 \%$ adalah dari variabel independen lain yang tidak digunakan dalam penelitian ini

\section{DAFTAR PUSTAKA}

Arikunto, Suharsimi. 2006. Prosedur Penelitian: Suatu Pendekatan Praktik. Edisi Revisi VI. Jakarta: Rineka Cipta

Arsyad, Lincolin. 1992. Ekonomi Pembangunan. Edisi Kedua. Yogyakarta: Bagian Penerbitan Sekolah Tinggi Ilmu Ekonomi YKPN

Berutu, Kasiman. 2011. Pengaruh Belanja Daerah, Investasi, Pendapatan Perkapita, dan Jumlah Penduduk terhadap Pendapatan Asli Daerah Kabupaten/Kota se-Provinsi Sumatera Utara. Tesis. Universitas Sumatera Utara. Medan

Boediono. 2012. Seri Sinopsis Pengantar Ilmu Ekonomi No.4: Teori Pertumbuhan
Ekonomi. Yogyakarta: BPFEYogyakarta

Elyani. 2010. Faktor yang Mempengaruhi Penanaman Modal Asing Berinvestasi di Indonesia. Jurnal Ilmiah Abdi Ilmu. Vol. 3, No. 1. Halaman 315-321

Ghozali, Imam. 2005. Aplikasi Analisis Multivariate dengan Program SPSS. Semarang: UNDIP

Hakim, Abdul. 2010. Ekonomi Pembangunan. Yogyakarta: Ekonisia

Hartono. 2004. Statistik untuk Penelitian. Yogyakarta: Pustaka Pelajar Offset

Maku, dkk., 2011. Analisis Determinansi Infrastruktur Jalan terhadap Produk Domestik Regional Bruto (Studi Kasus di Provinsi Nusa Tenggara Timur). Seminar Nasional Aplikasi Teknologi Wilayah 2011

Rustiono, Deddy. 2008. Analisis Pengaruh Investasi, Tenaga Kerja, dan Pengeluaran Pemerintah terhadap Pertumbuhan Ekonomi di Propinsi Jawa Tengah. Tesis. Universitas Diponegoro. Semarang

Sitompul, Novita Linda. 2007. Analisis Pengaruh Investasi dan Tenaga Kerja terhadap PDRB Sumatera Utara. Tesis. 
Universitas Sumatera Utara. Medan

Soeratno dan Arsyad, Lincolin. 1995. Metodologi Penelitian untuk Ekonomi dan Bisnis. Yogyakarta: UPP AMP YKPN

Sugiyono. 2004. Metode Penelitian Bisnis. Bandung: Alfabeta

Sukirno, Sadono. 2011.

Makroekonomi Teori

Pengantar. Edisi Ketiga.

Jakarta: Rajawali Pers
Suryabrata, Sumadi. 1998.

Metodologi Penelitian.

Jakarta: RajaGrafindo

Persada

Undang-Undang Republik Indonesia Nomor 1 tahun 1967 tentang Penanaman Modal Asing

Undang-Undang Republik Indonesia Nomor 25 tahun 2007 tentang Penanaman Modal

Undang-undang Republik Indonesia Nomor 6 tahun 1968 tentang Penanaman Modal Dalam Negeri 